\title{
Stereotype of the Other and the Bosnian Cultural Borderland Research Assumptions
}

\author{
Dr Justyna Pilarska
}

University of Wroclaw

\begin{abstract}
This paper tackles the issue of attitudes shaped in a culturally diverse environment, that can take form of a stereotype of the Other - a notion fundamental for the process of establishing own social identity. As far as culturally heterogeneous, complex societies are concerned, the image of the Other may acquire connotations different from those in culturally homogenous societies, hence it is worth to ponder over the way members of a cultural borderland construct their image of the Other, its features and specificity. Although the research is of preliminary, pilot character, it can provide with some assumption to a wider-scope project revealing the mechanisms of forming stereotypes and prejudices. Such knowledge, consequently, would be of great importance for pedagogues as well as formal and informal intercultural educators in determining the areas of compromise and conflict with given cultural codes, and cross-cultural practices. The theoretical framework of attitudes, stereotypes, and the concept of "the Other" is accompanied by the description of a cultural borderland as exemplified by Bosnia-Herzegovina, where the preliminary, qualitative research took place. Key impact in this regard is played by a relation between cultural pluralism and the process of shaping attitudes, as within given attitudes the individuals accept diversity and recognize it as an integral part of own, surrounding reality, crucially stimulating the process of opening to the understanding, cooperation and cross-cultural dialogue.
\end{abstract}

Keywords: stereotypes, prejudices, concept of the Other, qualitative research, Bosnian borderland, intercultural education

\section{Introduction}

...three possibilities [...] have always stood before man

whenever he has encountered an Other: he could choose

war, he could fence himself in behind a wall,

or he could start up a dialogue (Riszard Kapuscinski)

Contemporary intercultural education deals with number of sociological and cultural phenomena that require a constant investigation into the nature of cultural diversity. Multiculturalism considered as a distinctive feature of the modern societies implies the today's man ceases to function as a typical member of a specific cultural community, within a ready-to-use and an unchangeable identity. The complexity of interactions occurring in the cultural borderlands is reflected in the attitudes to the Other, and stereotypes of such notions as "otherness" and "alieness". In the pedagogical context, Bosnian multiculturalism, applying the philosophical notion of the Other (Alien) as defined by B. Waldenfels, allows to reveal the potential of daily experiences with the Other, that - in long term - could fundamentally enrich the cultural structure of a borderland, and provide pedagogues with new models of dealing with the cultural difference.

Attitudes constitute a form of divergent thinking, i.e. such, that contrary to convergent manner, recognizes and acknowledges various answers and solutions. Hence, if treated as an educational capital, they can provide a foundation for informal cross-cultural education allowing to "generate" ways to comprehend given social phenomena, entailing "flexibility of thinking" (Guilford, 1968). So, they can shape approach to cultural diversity, and reflect the way of exercising given stereotypes in a culturally diverse environment. Both flexibility and fluidity of thinking are linked to the degree of integration of attitudes (from strongly integrated to disintegrated) and its character (primary and secondary). Yet, it must be remembered that attitudes to given phenomena are related to the sense of self-esteem, its preservation, empowerment or protection. Therefore, if one finds his or her sense of self-esteem is threatened, he/she may adapt manners of diminishing the importance of a given object, phenomena or person. This, in turn, can evolve towards stereotypes, i.e. a fixed and 
oversimplified image or idea. Thus, such phenomena are worthy of methodological investigation, as stereotypes and attitudes towards the cultural difference can significantly shape theoretical framework of intercultural education. This pilot research project aims to initially recognize the attitudes of the Bosnian society members (with a multicultural background) towards the Other, and to establish whether (informal) cross-cultural education is a part of their everyday life experiences in this regard, or perhaps, it can become a foundation for such projects.

\section{Stereotypes and attitudes - theoretical framework}

Gordon W. Allport defined attitudes as "the most distinctive and indispensable concept in contemporary social psychology" (Allport, 1935, p. 789). Attitudes combine beliefs and behaviour towards a given object, subject to individual traits and influence of the socializing surrounding, yet they are not of a permanent character. Alice $\mathrm{H}$. Eagly and Shelly Chaiken define attitude as "a psychological tendency that is expressed by evaluating a particular entity with some degree of favor or disfavor" (Eagly \& Chaiken, 1993, p. 1). Such stand seems to be reflected in the findings of social psychologist Robert Zajonc, who proved that people are more likely to have a positive attitude on the object of the attitude when they are exposed to it frequently than if they are not, hence more repeated exposure of the individual to a stimulus is a sufficient condition for the enhancement of this attitude toward it (Zajonc, 1968, pp. 1-27)1.

Although amongst social psychologists there is not one consensus as for the precise definition of an attitude, it is commonly agreed that it is a permanent positive or negative assessment of people, objects and ideas. It, therefore, significantly influences the way of applying stereotypes, and consequently contributes to the process of generating prejudices and discrimination, as attitudes are related to the way others' values, feelings and behaviors are assessed, entailing stereotypes within. Thus, from the perspective of the contemporary formal and informal education it is of paramount importance to analyze attitudes and stereotypes present in a culturally diverse environment, define their most common objects, and provide with proposal of counteracting various forms of prejudice they can lead to.

Albeit attitude as such has manifold interpretations in the literature on the subject, as for social psychology two main discourses come to the forefront (Łukaszewski, 1974, pp. 190-193). The first one defines attitudes as a way of taking a stand of a subject to a given object, accordingly such definition entails assessment of a given phenomenon - positive, ambiguous or negative, however it is not an intellectual judgment, but one of emotional origin. Such assessments are expressed with relation to the activity of a given subject towards an object, rather than as expressed by the opinion. The individuals express judgment manifesting own attitudes, at the same time accepting, avoiding, praising, fighting or condemning a given phenomenon. The second approach points to the function of an attitude as a way of readiness to perform tasks of a given kind. By so, attitude is an unaware readiness of the subject to perform a given task and provides a motivating factor for such activity. Both perspectives of perceiving attitudes stress their regulating character towards the human's activity, additionally determining the complexity of the conduct of such person.

An attitude is composed of three elements:

Cognitive - cognitive information includes the facts people know and the beliefs they have about an attitude object;

Affective information consisting of people's feelings and emotions about the object;

Behavioural information, i.e. knowledge about people's past, present, or future interactions with the attitude object (Smith et al., 2015, p. 237).

Thence, attitude is considered as a relatively permanent cognitive, emotional and behavioral organization of a subject, related to given object or a class of objects. It does not only directs reactions of an individual, but determines its dynamics, so attitudes lie at the foundation of a personality.

A fully shaped attitude is conditioned not that much by biological or primary needs, but higher ones. Hence, the object of the higher needs corresponds to the object of the attitudes. It can concern aesthetics, art, science, society, morality, ethnicity, politics, religion or nationality. Therefore, it can be linked to such values as democracy, understanding, compromise, dialogue or cross-cultural cooperation, crucial for the counterbalancing of negative stereotypes.

\footnotetext{
1 On that account it can serve as an assumption for some intercultural, educational projects.
} 
Bearing in mind the fact that attitudes and stereotypes are shaped by the influence of various interactions of an individual with other people, as well as by the theory of social learning entailing socialization, education, enculturation etc., it provides a foundation for intercultural education that could prevent from instilling negative attitudes leading to prejudices, to which social and cognitive factors contribute. It can stem from stereotypes, which constitute "positive or negative beliefs about a group's characteristics" (Smith et al., 2015, p. 187).

The relation between an attitude and the stereotype is of key importance. As far as various structural components of the attitude and the stereotypes are concerned, the following differences regarding emotions, knowledge or their modification can be distinguished.

Table 1: Constitutive differences between an attitude and a stereotype.

\begin{tabular}{|l|l|l|l|l|}
\hline & Emotions & Knowledge & $\begin{array}{l}\text { Relations between } \\
\text { knowledge, emotions and } \\
\text { behaviour }\end{array}$ & Modification \\
\hline Attitude & $\begin{array}{l}\text { Emotions are } \\
\text { constitutive for the } \\
\text { attitude }\end{array}$ & $\begin{array}{l}\text { Specific type of } \\
\text { knowledge, not a } \\
\text { purely descriptive one, } \\
\text { but still entailing } \\
\text { evaluative traits }\end{array}$ & $\begin{array}{l}\text { All the components of the } \\
\text { attitude imply each other i.e. } \\
\text { knowledge and emotions } \\
\text { both determine the } \\
\text { behaviour }\end{array}$ & $\begin{array}{l}\text { Direct change of attitudes is } \\
\text { seldom, rather taking place in } \\
\text { an indirect manner; } \\
\text { Change of knowledge or } \\
\text { behaviour has impact on } \\
\text { emotions and vice versa }\end{array}$ \\
\hline Stereotype & $\begin{array}{l}\text { Emotional } \\
\text { component occurs, } \\
\text { but is not } \\
\text { indispensible }\end{array}$ & $\begin{array}{l}\text { Knowledge doesn't } \\
\text { have to be reliable nor } \\
\text { actual - it can be a } \\
\text { pseudo-knowledge, } \\
\text { and a constructive } \\
\text { component }\end{array}$ & $\begin{array}{l}\text { Co-relations of three } \\
\text { elements take place to a } \\
\text { small degree, hence such } \\
\text { relation is marginal }\end{array}$ & $\begin{array}{l}\text { It can be subject to } \\
\text { modification, yet it is } \\
\text { challenging, and requires a } \\
\text { complex approach }\end{array}$ \\
\hline
\end{tabular}

Source: own study based on: Macrae, C., Ch. Stangor, and Hewstone M. (1996). Stereotypes and Stereotyping. The Guilford Press: New York, pp. 27-41.

It is worth to emphasize the fact that stereotypes reveal their negative nature especially in the context of prejudice and discrimination. Stereotypes can be "learned through personal experience with group members, but may still be biased because of emotions that arise during cross-group interactions" (Smith et al., 2015, p. 150). According to C. Macrae, Ch. Stangor and M. Hewstone (1999, p.89), if stereotypes correspond to the cognitive component of the prejudice, it can be assumed that strong stereotypization is to be linked with the increase of prejudices. The latter are explicitly defined as negative attitudes, often referred to an individual as a member of a given group, regardless of the fact whether such group stereotype accentuates individual traits of a given person. Prejudices, similarly as other attitudes, contain cognitive element (such as irrational beliefs on the stereotyped person), affective aspect (disinclination), and are related to will (such as behavioral tendency to avoid the stereotyped person).

Attitudes and stereotypes are significantly determined by social and cultural circumstances that play a key role in the process of socialization. Since culture involves ideas on the reality defining the degree and form of the belonging to a given cultural group, the personality is influenced by ideologies, social norms and behavioral patterns, i.e. attitudes, too. Common attitudes towards own nation, tradition, distinguished persons or the neighbouring countries do not condition uniformity of the national culture, as relation with a given nation or social class is predominantly determined by small social groups, particularly by the family and educational institutions ${ }^{1}$. Consequently, cultural diversity of the given communities conditioning the origin of social norms, beliefs, and stereotypes, crucially influence range of the possible attitudes.

The role of culture with regards to given aspects of the attitudes and stereotypes can be outlined as follows:

Cognitive: Each culture includes repertoire of statements on the reality, beliefs and convictions providing some elements of the knowledge or systems of science contributing to religious or ideological doctrines;

Emotions: Emotional reactions are tightly linked to the bio-mental layer of personality. Therefore they function within dynamic relation to the process of socialization and internalization of the norms and judgments. The manner of internalizing

${ }^{1}$ This can provide another psychological/pedagogical premise for the establishing of cross-cultural educational projects. 
the cultural code in a given culture taking place upon socialization or upbringing crucially determines emotional approach towards an object of a given attitude; i.e. an object that constitutes a cultural and social element of reference of a given group;

Behaviour: Behavioural patterns are strongly influenced by the generally accepted norms of conduct.

Thanks to social and cultural life, attitudes presented by given individuals crucially influence the process of explaining given social facts. As explanatory hypotheses they help to understand the surrounding reality, and also to take appropriate stand towards it. If the attitudes towards cultural diversity are negative, they affect the perception of such social and cultural reality, hindering dialogue and cross-cultural cooperation. On the other hand, such negative attitudes or stereotypes of the representatives of other culture can be counterbalanced by appropriate educational tools, facilitating cross-cultural communication. Therefore, the attitude to the Other can provide an information on the potential of informal cross-cultural education in the culturally diverse societies, and the chances, circumstances and conditions of implementing such projects.

\section{The concept of the Other ${ }^{1}$}

The postmodern sociology and politics of difference has played a big part in the current European cultural discourse, challenging the universalistic notions of the subject, identity, society, inequality and knowledge. The category of the Other corresponds to the discourse of difference, (cultural) diversity and so on, providing a powerful resource for the analysis and critique, whereas the Otherness is "fundamentally about cultural denigration and exclusion" (Seidma, 2013, p. 3).

In the process of socialization the individuals are subject to the process of social categorization, hence the world around is divided into "them" and "us", establishing a boundary between in-group (us) and out-group (them). Consequently, social identity theory implies that group members of an in-group tend to seek and find negative aspects of an out-group, enhancing their self-image. Henri Tajfel, an american social psychologist, implied that that the subsequent stereotyping is based on a standard cognitive process, namely the tendency to group similar objects together. In doing so, members of given groups display inclination towards exaggeration of the differences between groups, and on the other hand highlighting similarities within own group (Tajfel \& Turner, 1979). Nonetheless, the process of in- out-group classification, if taking place in a culturally diverse environment, is not linear as it naturally, due to its cultural dynamics, involves the "interfering" role of the Other. Thus and so, the presence of the Other questions this explicit classification as it confronts unambiguous identity constructs with cultural difference, that may become incorporated to the image of the "Self" and "Me". In his works, The Question of the Other (2007) and Phenomenology of the Alien (2011) the German philosopher Bernhard Waldenfels emphasized constitutive plural character of experience, in which alienness/otherness is constantly involved. Waldenfels' philosophical orientation - characterized both by a close dialogue with the doctrine of Maurice Merleau-Ponty and a thorough confrontation with thinkers such as E. Husserl, M. Foucault, E. Levinas, P. Ricoeur and J. Derrida - corresponds in this regard with the J. Habermas's communication discourse which negating any "radical alien", acknowledges the participation of a "relative alien", who can therefore always be part of a successful strategy of inclusion and intercultural discourse. Therefore, according to Waldenfels, the alien,

"does not arise from a mere process of delimitation [of self and other]. It emerges from a process which is realized simultaneously as an inclusion (Entgrenzung) and an exclusion (Ausgrenzung). The alien is not opposed to the same, rather it refers to the Self (aủtó, ipse), to myself or to ourselves, including the "sphere of ownness" ...from which it escapes. What is alien does not simply appear different, rather it arises from elsewhere. The sphere of alienness is separated from my sphere of ownness by a threshold [...]. (2007, p. 7)".

Thus, the encounter with the Other is a multifaceted and multidimensional phenomenon that permeates everyday experiences of those in the cultural borderlands. The Other, in the realm of subjective experience, can confront members of a culturally diverse community with their own beliefs on what is "Mine" (familiar) and what is Alien (unfamiliar), in terms of cultural code. As Waldenfels explains:

\footnotetext{
1 The notions of The alien and the Other come from B. Waldenfels' The Question of the Other (2007). Waldenfels uses the term "other" for what is consistently rendered elsewhere in translation as "alien". He justifies this by stressing that the difference between "other" and "alien" is not as explicit in English as in German.
} 
"in the call of the Other which breaks the purposive circle of intentionality as much as the regulative circle of communication, the alien emerges in actu. [...] Peculiar to the call of the Other is the fact that both forms of Anspruch, i.e., appeal and claim, are intertwined. In the call that I receive, there is something that is demanded from me..." (2011, p. 37)

Interestingly, Waldenfels projects an image of the Other freed from the logical and ontological opposition to the category of "the same", as the phenomenological framework allows to avoid the abstract duality otherness/sameness, "placing the other on the very plural and unstable terrain of factical experience" (Menga, 2001, p. 7). Thus, it is exactly this constitutive plural character of experience, in which "alienness" is constantly involved, what makes Waldenfels's phenomenology ${ }^{1}$ particularly open to confrontations with several discourse domains (ibidem), as it can be tracked down in some culturally diverse communities. Waldenfels, however, locates his constitutive presence of alienness within the "own" not only in the realm of "subjective" experience, but also at a more extended level, which concerns the orders of experience, in whose domain our lives acquire their general meanings and orientation (Waldenfels, 1987). Accordingly, as Frank Haike emphasizes "Waldenfels argues that we perceive the alien as a provocation or as something that makes us uncomfortable. The alien shows us that there is something else that exists outside of the self. This creates both fear and desire in us" (Haike, 2008, p. 328) ${ }^{2}$. It proves that meeting the Other in a cultural borderland can facilitate the Self to become engaged in relations marked by reciprocity and symmetry (Leistle, 2014, p. 55). And, although contemporarily there are various manners of dealing with the experience of the Alien, i.e. from extreme hostile approach, and through appropriation and domination which "take away its otherness or alienness, and reduce it to an extension of the Self" (Waldenfels, 2007, p. 38), as for the prerogatives of cross-cultural education the most desirable pattern is discursive narration and dialogic interaction with the Other. Therefore, the latter is worthy of methodological investigation taking into account various multicultural societies that deal with a cultural difference on a daily basis. It can be subsequently assumed, that the interactions with the Other generate a potential area for the cross-cultural education.

\section{Bosnian cultural borderland}

Cultural borderland is a notion created to accommodate a multicultural society, and concerns a space created when two or more cultures and races occupy the same territory. According to Foley (1995), the space should be considered psychologically and politically, as it generally refers to a psychological area at the conjuncture of two cultures. Nonetheless, cultural borderland is also a "political space in which ethnic groups actively fuse and blend their culture with the mainstream culture" (Foley, 1995, p. 119). The borderland is also a generative space, yet is not only where the defiled/civil divide is publicly staged, but it is productive of new hybrid selves (Eyal, 2006).

The category of a cultural borderland is a primary concept for the conceptualization of the community microspace in a culturally diverse society. In the literature, the borderland as such has many interpretations. One of the applicable theories concerning borderland is put forward by Jerzy Nikitorowicz, who classified and defined specific types of the borderlands. According to the author, a cultural borderland is an area "(...) of difference, sense of otherness, and diversity where comparisons, discoveries, amazement and negotiations take place (Nikitorowicz, 1995, p. 11).

Thus, borderland in multicultural education is perceived as a psychological space in which bi- or multicultural identities can be shaped (Pilarska, 2014), as it is constituted by "areas of contact among different groups of people with different value systems, cultural traditions, patterns of behaviour and languages" (Kubica \& Rusek, 2014, p. 9). Grażyna Kubica and Halina Rusek highlight the fact that:

"In the borderland situation, a particularly visible problem is the identity of individuals and social groups who, since they live on the cusp of two or more cultures, are constantly in touch with the 'other'. The question of identity and thus 'who am l' and 'who am I not' is particularly clearly revealed in the borderlands [...] the question is in fact sharper wherever we are dealing with marked differences, where the "others' are often "strangers" (who, in some cases become "ours"), where value systems and cultural patterns compete and often lead to their confrontation" (Kubica, Rusek 2014, p. 9).

\footnotetext{
${ }^{1}$ Waldenfels has characterized his own work as "a further development of the existential-structural phenomenology in Merleau-Ponty's sense" Friesen, N. (2014). Waldenfels' Responsive Phenomenology of the Alien: An Introduction. Phenomenology \& Practice, 7(2), 6877. Concurrently such phenomenological stance corresponds to the applied strategy of inquiry (phenomenology) of this pilot research design.

2 This desire, in turn, could be utilized within the framework of some educational schemes that would support the cross-cultural framework of such encounters.
} 
Experiencing contact with the cultural difference (personified by the Other) entails confrontation of (at times) competing or corresponding systems of values and cultural patterns, thereupon such contact could threaten, or quite the contrary, enrich integrity within cultural or social identity. In the past, Bosnia-Herzegovina was subject to extremely contradictory powers affecting not only its current political shape, but also framing its social nature and the specificity of intercultural communication taking place in the cultural borderland. The latter is established by a heterogeneous society in terms of ethnic, confessional or national provenance, providing a unique example of synthetic form of eclectic cultural code. Bosnian society is constituted by three major ethnic/confessional groups, namely Bosnian Serbs, Bosnian Croats and Bosniaks. As proved by previous findings of the author (Pilarska, 2011) Bosnian Muslims provide extraordinary example of unconventional pattern of perceiving own identity, being a combination of various, at times contradictory, cultural codes, such as south-European (Yugoslav facet), ottoman, Mediterranean, Muslim and Slavic. As J. Žiga stresses:

"multicultural character of Bosnian society was visible by a bear eye at almost every step [...] for centuries Bosnian people lived in mixed villages, towns, and from only fairly recently in apartment buildings. And, it never caught anybody's eye but was accepted as a usual and everyday way of life" (2001, p. 58).

Such acknowledgement of Bosnian cultural borderland is also confirmed in the works of Š. Međedović, who claims that: "all contents of its social being - language, customs, tradition, culture, multicultural and confessional pluralism and tolerance, have never been lost even under the imperial authority [...] (1996, p. 19). Despite many misconceptions about the "permanent intolerance of the people from these grounds, "conflicts of civilizations", and the similar" (Žiga, 2001, p. 83), the cultural and social experience of Bosnia and Herzegovina "testifies of something entirely different, this is, tolerance, openness towards the other and different" (Žiga, 2001, p. 83). Taking the above into consideration such cultural and social setting provides a thought-provoking field of research for the perception of the Other that could be further investigated within the range of appropriate quantitative or qualitative methods. Such research design could provide an answer to the question whether the Other is perceived in a culturally diverse society differently than in a homogenous communities, how specifically is this notion understood in a multicultural Bosnia-Herzegovina, and whether Bosnian approach provides premises for informal and formal cross-cultural, educational projects.

\section{Methodology of the pilot research ${ }^{1}$}

Since experiencing cultural diversity is often subject to regional or local cultural contexts, historical memory and the nature of intercultural relations in Bosnia-Herzegovina outline a specific area of attitudes towards "the culturally other", as reflected in the explorations within the framework of qualitative research. With reference to the theoretical framework of the concept of the Other it is worth to stress that Waldenfels "can be traced back to that constellation of thinking which, by putting at its center the phenomenon of intersubjectivity, attempts to show how every domain of human experience is faced by a constitutive intervention of alterity as an element calling for constant questioning and inevitable transformations" (Menga, 2001, p.7). Thus, the pilot study exercised the phenomenological approach, which allows the researcher to understand how one or more individuals experience a phenomenon, followed by relative epistemology, i.e. individual and group justification with varying standards and subjective, personal and constructed nature of the reality (ontology). In this case the studied phenomena is the experience of contacts with the Other, own manners of its interpretation, assigning significance to such encounters, etc. The emphases of qualitative research stress the importance of generating theories from the data collected during fieldwork, hence the research objective is to describe, explore and discover within wide-angle examination of the phenomena, acknowledging the reality as subjective, personally and socially constructed. The qualitative research methods were applied as by their nature they allow "to gain an understanding of the underlying reasons and motivations for actions and establish how people interpret their experiences and the world around them" (Macdonald \& Headlam, p. 69). Remembering that the "major concern in qualitative research is with richness of information, and so sample size is not a determination of research significance" (Ebrahim, 1995, p. 206) and since qualitative field research is "about in-depth understanding of specific individuals, rather than studying the general characteristics of a large number of individuals across specific variables" (Ebrahim, 1995, p. 96), the systematic non-probalistic sampling was applied. The respondents were selected upon the research design objective, i.e. they selection concerned the members of the Bosnian society, i.e. Bosnian Serbs, Bosnian Croats and Bosnian Muslims, 10 for each of the ethnic groups. Collection of qualitative date took place

\footnotetext{
1 This paper is an outcome of own pilot research project carried out individually within the framework of the internal grants for researchers at the University of Wroclaw. The preliminary research was carried out by the author in August 2015 in Sarajevo, Banja Luka and Mostar, Bosnia-Herzegovina.
} 
applying interviews with an open-ended questions. Unstructured interviews as the applied technique of data collection allowed to obtain the information in a form of free discussion, where respondents were encouraged to relate freely they experiences, permitting a free flowing account of the personal and social context of beliefs and feelings. The data was recorded using the Dictaphone, i.e. the responses were recorded and transcriptions were used as the material for the analysis. Additional field notes were made to capture some non-verbal sings accompanying the speech or discourse of the respondents (some expressed emotional attitudes, agitation or reflectiveness). Applying phenomenological data analysis, the search for patterns and some holistic features of the comments made by the respondents was possible, and so the results could generate the emic representation of the insider viewpoint, entailing multiple perspective. The qualitative nature of the data analysis enabled the search for relations between the ideas, expressions and viewpoints declared by the respondents. In such way two processes were embraced. i.e. deducing what the respondents meant from what they say and secondly, understanding the implications of what they said. Consequently, the research was subject to descriptive codes, so the results could be presented within narrative form, due to the fact that in the framework of qualitative paradigm "it is possible to undertake subjects reaching beyond this, what is objective and measurable, allowing to tackle issues linked to assessment, values and experiences" (Bauman, 1998). Since within own research application of such methods allows to undertake unrecognized topics, "which the researcher rather has a feeling of, rather than possess a certain knowledge" (Bauman, 1998), it was inadequate in such circumstances to apply hypotheses due to the natural case of unfamiliarity with given task, that a researcher wanted to explore. Consequently, if there are no hypotheses, there was no necessity to verify or falsify such notions. The main research question was how the members of a culturally diverse Bosnian society perceive and picture the image of the Other. The pilot study took place in Bosnia-Herzegovina in August 2015. The research was conducted in Bosnian language (with no assistance from an interpreter) among Bosnian Croats, Bosnian Serbs and Bosniaks, 30 in total, ${ }^{1}$ in a qualitative manner within implementation of open unstructured interviews, which as a discovery-oriented method was used to obtain opening information, providing with some preliminary findings and foundation for the further investigation.According to some of the research narratives, the sense and notion of "the Other" emerges as a reaction to the lack of understanding of the respondents' culture, i.e. their customs, religion and tradition. In such case the researched link "otherness" to the lack of understanding for their culture, the nature of their confession (e.g. Islam) and its cultural connotations:

The other is someone who doesn't understand my need to cultivate the tradition of islam and its customs; someone who attacks my autonomy in this regard [R1]

If somebody doesn't respect my values, doesn't understand its importance and key role it played in shaping cultural heritage in the entire Balkans, then l'll never find a common language with such person [R2]

Own cultural group is therefore perceived as the dominant and exclusive, whereas unfamiliarity with the respondents' cultural background implies in their opinion lack of respect towards their own heritage, and builds up an image of the Other as someone who does not have the knowledge, nor recognition for the respondents' culture.

Another factor stressed by the researched concerned the key values such as religious affiliation, which can potentially serve as a ground for dialogue, yet if internalized insufficiently (or subject to excessive pride and sense of superiority) can be reflected as sort of chauvinism, as in statement as below:

The other is someone who doesn't believe in what I believe; he can speak some other language and have some other name, but if he doesn't understand power of my religion I will not communicate with such person [R3]

Thus, the Other is someone who doesn't respect and understand the foundation of a given faith that shapes the cultural and spiritual world of the respondents2:

It's someone who doesn't understand and attacks Islam [R4]

It's for sure someone who doesn't understand my customs, culture, language or history. It is not someone from here; not an European from the West either; it is and abstraction [R5]

\footnotetext{
1 Each respondent's statement was codified as $\mathrm{R}$ for respondent and corresponding number of the interviewee.

2 In the light of the above, the question of preparing cross-cultural education well-grounded in the local context could be raised.
} 
Serbian culture provides ready answers as to the questions who I am, how to live and how to think, what is my place in my culture; it's my heritage so if someone doesn't understand and follow that it's hard for me to see similarities between such person and me; [...] if such perons attack or diminishes its worth, he is the other [R6]

Withdrawn, hermetic cultural identity perceives diversity in terms of "the otherness" stemming from the conviction that "what is mine is the best", hence, culturally most valuable. Interpretation of this type of phenomena therefore takes place from the angle of own culture. Accordingly, "the other" comes across as someone who provides a real threat to the members of a given group, someone questioning its continuity:

It's someone who doesn't understand our culture in the Balkans; who started the war; who divided us; to me those are Croats who chased us from Kraijna; who hurt us...[R7]

Those that don't belong to the Muslim culture [R8]

Those who don't understand islam don't understand us; I feel among "Others" when I am along those who cannot respect our culture [R9]

It's someone who chased us from our house during the war and betrayed; someone who is not a Croat, as everything related to Croatia is familiar to me [R10]

Aggression, disinclination and passive antagonism accompanied by intolerance dividing between this what is "familiar" and this what is "strange" often reflect lack for the need to get to know and recognize the very existence of diversity. Hence, own culture is perceived as the "superior" and the only "righteous" one, followed by the need of recognition to a set of "own" features and values acknowledged as "common" for everyone. Consequently, the sense of the otherness is identified with lack of understanding of the above:

I don't understand people when they don't speak my language, or the language I know; when they don't follow the rules I do; or behave contrary to what I find as normal; then I think such person is "the other" [R11]

Thus, it can be anyone who doesn't belong to the same cultural group, doesn't identify with the respondent's group, etc. Such attitudes reveal strong attachment to own cultural identity with little space whatsoever left for the flexibility or openness towards other cultural influences. It is an important signal for pedagogues, teachers and educators that should introduce cross-cultural contents to all spheres of life, regardless of its formal or informal character, within the framework of a lifelong learning. Taking it into account a rather discernible conclusion is revealed, i.e. lack of intercultural education, entailing lack of knowledge on the representatives of culturally diversity, implies xenophobic approach and sense of threat to own identity.

"Otherness" can be understood with regards to what is "external", i.e. as reflected in the statements of the respondents with reference to the attitude towards "the West" and its presence in Bosnia-Herzegovina. The division goes along the line we - the Balkans (in-group) them - the West. Consequently, ethnic diversity is not perceived as something unfamiliar, as the sense of the latter is rather expressed in the ironical perception of the Western presence:

The other is the West with its monopoly of knowledge about Bosnia [R12]

All those who have come here and want to enlighten us as if we couldn't manage without them [R13]

Serbs, even if they want to, cannot become "the other", the different, as we know each other too well; but if someone doesn't respect my values I don't understand such person either; it's like with this EU and Western presence, they look at us as at aliens and think we will kill each other without them [R14]

It's someone who doesn't understand my culture and customs, attacks it and doesn't understand how unique it is; as everything in the Balkans [R15]

The other is someone who doesn't understand the character of the Balkans; when those from UN come and ask us if we can live together and not kill each other, and how to explain it to them; it's not someone from the Balkans but beyond [R16]

Well, it is not someone from here [R17]

Interestingly, the image of cultural familiarity and sense of "owness" is extended to all Balkan nations and cultures. The reflections are accompanied by a strong sense of the uniqueness of the Balkan culture linked to the presence of various 
cultural elements in the social surrounding. Therefore, "the otherness" is related to the lack of understanding of the idea of the Balkan melting pot and its specificity. Hence, "Otherness" is searched for in these aspects that question common Bosnian coexistence:

The other is someone who betrayed Yugoslavia, common ideals, peace, common wealth and solidarity[R18]

Those are these who destroyed Yugoslavia, denied the community for money and power [R19]

Interestingly, the "Balkan community" can provide some common ground of a cultural compromise, encounters and area of mutual recognition.

Taking the above into consideration, the sense of otherness is assigned to those persons and factors that "betrayed the community", so it is interpreted as an attack on the "idea of Yugoslavia":

It's someone who doesn't understand us and this, what was being built in Yugoslavia for years [R20]

I have never been thinking about it, that what scholars are for, especially those who come here and select these opinions, as we simply live here amongst each other, as the city under the siege for 3 years taught us solidarity the best possible way [R21]

A common foundation of the culture with reference to the "Yugoslavian" heritage entails some local, regional connotations that could be also taken into consideration while working out educational schemes for cross-cultural education. The sense of otherness is therefore often linked to the lack of respect and understanding of the nature of the Balkans, its culture and social relations in Bosnia, which altogether appear as a set of commonly declared values that allow to identify with a wider social context in the region:

It's not that I think of my culture in the categories of familiar/strange; how could I if I live in Bosnia yet I'm half-Croat halfMontenegrin? What would be "the other" for me then? Due to my origin I'm part of all these cultures after all [R22]

Moving beyond the homogenous frameworks of cultural interpretation, it is becoming a challenge to explicitly define what/who is the cultural other. Moreover, partnership-based relations and a sense of symbiotic relations moving beyond ethnic lines are evident:

There are no others'; others are those I don't know as I haven't had the opportunity to meet; here in the Balkans we know each other well; there are no strangers here [R23]

Others are those who tell us we've been always hating each other; they are the strangers; we've been living together for centuries and I will never call them "the others", even if some of them provoked the war [R24]

Consequently, no one is a member of own, one, isolated group, as (s)he defines own identity in relation the members of other groups:

We think of ourselves as Bosnians - it is already a mixture, a creation of various pieces, a patchwork; if you ask if someone from here is the "other" to me as he or she is not a Catholic or Croat as I am - these are stereotypes and we never thought of each other this way, because our country is multicultural and has diverse people of various nationalities I think we should respect each other; the war left a huge imprint on us and people don't live in harmony as before so no matter how much others can differ, we need to know how to live together [R26]

No one is "the other" here; what an artificial division; even if it means something that is not the same it could still function together; we have always lived one next to another, so may be the others are those who started the war; here we are all on the same boat [R27]

The above prove the degree of mutual process of enrichment, coexistence in a given local environment as well as historical memories result from the idea of a given cultural community of all the nationalities, ethnicities and confessions in BosniaHerzegovina. It is reflected in the following remarks:

Well, today they say we are different, so to me the fall of Yugoslavia and the war affected this; In the past we used to be a one, big country, Bosnians, Croats and Serbs, we were great and together and now we are a country of various cultures 
and territories; sometimes I wonder if we really differ and then I think how this country used to look like. And it was really $\operatorname{good}[R 28]$

When I think of "the other" I don't have anything particular on my mind, but I think that people now see others because of their ethnic or religious origin, and it's very dangerous, honestly I don't use such word as I treat the entire nation, planet and the world as the same, no matter how different they are; a black man, a Serb a Croat, an orthodox, catholic, Muslim or a white man; so religion, nationality or color of the skin doesn't matter to me at all and don't mean someone is "the other", and when I see people who come from other countries I want to get to know to them and their culture [R29]

I don't see people as others but I think in Bosnia some say those are ethnic majorities which are seen by them as complete others and therefore they have prejudices against them and deny equal rights to them; I don't think of who is the other but I know that in Bosnia some Bosnians think that Serbs and Croats are different, but I believe it's not true; we are all first of all people, no matter if they say someone is a Serb, a Croat or a Bosnian [R30].

Taking the above into consideration, it can be assumed there are some areas of "otherness" entailing emotional aspects of the attitude to "others", disabling the process of opening up to the cultural diversity. Sense of the "otherness" towards given values, ideas or subjects occurs when they question or show lack of recognition for the Balkans and specificity of the region. Thus, knowledge, recognition, respect and sensitivity to the local, cultural context come to the forefront, although subject to some Yugo-nostalgic sentiments.

It is also expressed with regards to those that do not understand the customs and traditions of the Bosnian culture. Yet, the latter, as far as educational activities are concerned, can be acquired through understanding and comprehension via interactions and dialogue. Undoubtedly, memory of the war after the fall of Yugoslavia contributes to some strongly emotional attitudes to others, being part of the regional community. Nonetheless, interestingly, as the above signals, negative statements of prejudicial nature are scarce.

The preliminary review of the respondents statements allow to conclude that the Other as a notion reflecting cultural diversity is actively present within the area of a cultural borderland, and affect the way social identities are constructed. In some cases the Other is seen as the reflected $\mathrm{Me}$, a coherent part of the cultural surrounding and social environment, for some it provides a challenge to incorporate cultural contents of diverse origin to own system of values, and other respondents, although in minority, perceive the Other as someone threatening their sense of cultural integrity. Thus, it can serve as a point of reference for cross-cultural educational projects and a point of departure for a further, in-depth research exploration.

\section{Conclusions}

The pilot research concerning the image of the Other projected by members of a culturally diverse Bosnian society aimed at the reconstruction of the individual's understanding of the notion of the Other in the Bosnian cultural context. As a result, it enabled to reveal areas of the cultural familiarity and the sense of bond, consequently defining some areas of experiencing the Other. Participants of the cultural borderland work out together their cultural community incorporating the values, traditions and customs that constitute a typically Bosnian (Balkan) cultural code, hence not much that comes from the Balkan culture is perceived as an "Alien", strange or "Other". It is possible due to everyday interactions with the representative of various cultural traditions that altogether generate a cultural code comprehensible to all members of the cultural borderland. Hence, the respondents would reply that "the other" is someone who doesn't know their customs; ergo - even if a Muslim doesn't follow Christian rites, yet is aware of the importance of such tradition, through such awareness given rites naturally become "internalized" and incorporated to the image of the nearest cultural landscape. It occurs to confirm implications that "we only become ourselves by responding to the Other; hence otherness becomes one of basic issues in human life allowing for introduction of innovations in the behaviour and beliefs of the Self" (Wełnic, Fislak, 2008, p. 182).

Attitudes towards the Other stemming from the stereotype of the latter have impact on the course of social interactions, perception of cultural otherness, hypothetical ways of cooperation, and cross-cultural communication. Moreover, they also affect the process of dialogue, and influence the dynamics of a civic society. In a cultural borderland extreme attitudes can generate cultural conflict due to the dominance of homogeneity of one group and marginality of others, as some of the respondents imply. Attitudes in a multicultural society often concern negative stereotypes of "the otherness" and can become subject to xenophobia with regards to the perceived and misunderstood difference. Hence, the sense of otherness 
can concern all the elements that are central in the system of values of given persons; e.g. ideas, phenomena, historical figures, etc., everything that composes of historical memory and cultural tradition of a given social, ethnic or national group.

The analyzed part of the qualitative research pointed to some aspects of the perception of cultural unfamiliarity and the sense of "otherness" in a culturally diverse environment. It allows to conclude that sense of otherness or its lack is subject to everyday experience and interactions with the representatives of the other culture. Thus, the more opportunities are provided to encounter the other, the greater chance he/ she will become a coherent part of the cultural surrounding of those involved in such encounter.

Such conclusion is of great importance in case of attitudes towards ethnic or national diversity in a cultural borderland. If attitudes to Others imply (as pointed in the theoretical part) given approach, i.e. positive, ambiguous or negative, they are of emotional character and can be shaped during the process of pedagogical intercourse, dialogue and other forms of educational communication (though projects, task assignments, etc). Moreover, attitude as such entails a readiness to perform tasks towards a given object. Hence, if a stereotype - which is a form of an attitude - has a positive connotation, it can generate constructive, positive relation with the object of a stereotype (e.g. the Other). All things considered, since the stereotype and attitudes are of regulating character, they can be exercised in the course of formal or informal crosscultural education to deconstruct prejudices and upon the process of becoming familiar with the Other incorporating its image to the multicultural landscape of ontological familiarity. As the findings of social psychology confirm, most persons are capable of assessing highly the phenomena that are favorable from the perspective of their attitudes, whereas those that are unfavorable are degraded (Smith et al., 2015). Hence, if the process of education could provide the learners with ways of becoming familiar with the Other, not classifying him or her as an objecting threatening the sense of integrity or self-esteem, a common ground for understanding and interaction could be established. Such differences do not have to be negative as they can provide a chance for contact and mutual enrichment. It can be, however, reached only through compromise, tolerance and cross-cultural learning. The results of the pilot study prove there is some degree of the recognition and curiosity for the Other, that encompasses the regional, "local" (Balkan) context, yet it should be definitely strengthen within the framework of some cross-cultural projects. The distinct aims of intercultural education can be summarized under the headings of "The four pillars of education" as identified by the International Commission on Education for the Twenty-First Century (Delors, 1996). According to the conclusions of the Commission, such education should, among others, make communication possible, develop an understanding of other people and "an appreciation of interdependence in a spirit of respect for the values of pluralism, mutual understanding, peace and cultural diversity. [...] the learner needs to acquire knowledge, skills and values that contribute to a spirit of solidarity and co-operation among diverse individuals and groups in society" (Ibidem, p.97). As some of the states from the respondents' narratives prove, lack of knowledge on the cultural code of a wider cultural circle can generate xenophobic attitudes. On the other hand, the most interculturally desired values encompass open-mindedness, solidarity, sensitivity, empathy, willingness to find compromise, and the willingness to redefine own views. Therefore, intercultural education, whether as formal or informal, entail openness, tolerance and democracy in order to enhance the efficiency of intercultural relations, increase tolerance and acceptance towards those who are different, and encourage others to perceive, accept and respect diversity for mediating social relations (Badelau 1990). According to contact hypothesis that "under certain condition, direct contact between members of different groups can reduce intergroup stereotyping, prejudice, and discrimination" (Allport, 1954, $p$. 17) and bearing in mind that "human cultures are neither necessarily coherent nor always homogenous" (Lugo, 1997, $p$. 51), the following conclusions can be drawn:

The more contacts with cultural difference occur, the weaker is the projection of Otherness in terms of culture;

The stereotype of the Other largely depends on the familiarity of the "stranger" with the cultural specificity of mutual communities - it proves that intercultural education can help in such communities and societies to learn mutual understanding and respect of a heterogeneous, cultural heritage;

The wider scope of cultural background, the narrower image of the other is generated - introducing educational projects that would establish a common ground for intercultural communication, getting to know other traditions, customs and ways of living can help bring such members of a multicultural reality together;

Attitude formation in a cultural borderland facilities broadening the scope of accepted traditions, customs, rites and elements of cultural that compose given borderland, enriching social life, process of cultural communication and conceptualization of own identity; 
Shaping attitudes in the atmosphere of cultural pluralism is related to the influence and impact of many, often contradictory social and cultural influences; hence difference as such plays important part in the cultural system;

Negative stereotype of the Other can be balanced by teaching on both cultural diversity of human societies and processes of cultural interactions, relations, fusions, exchange and the transformation of cultures initiated by intercultural contacts; as such, "dynamic approach emphasizes categories like 'between', 'interaction', 'dialogue', 'cultural borderland' and 'change' placed within the interactionist perspective" (Błeszyńska, 2006, p. 75).

Bosnian cultural borderland due to its culturally diverse nature is interspersed by the presence of the Other and there are various strategies participants of such environments can adapt to deal with the Other. This issue, in the context of the priority of intercultural education and threats to a multicultural societies omnipresent in the European area, is worthy of attention and profound investigation, so appropriate educational and pedagogical schemes can be applied in order to prevent from development of negative stereotypes and prejudices, questioning dynamic, yet productive multicultural status quo of some communities. Research on negative attitudes and stereotypes should be undertaken in culturally diverse societies as their deconstruction could reveal the areas of conflicts and compromise, enabling the possibilities of counteracting prejudices and using the category of the Other as a potentially cultural capital that could enrich such heterogeneous communities. Ignorance towards cultural abundance of contemporary societies can lead to xenophobic attitudes and prejudices, questioning the paradigm of cross-cultural dialogue, yet the antidote can be found within intercultural educational schemes.

\section{References}

[1] Allport, G. W. (1935). Attitudes. In: C. Murchison (ed.). A Handbook of Social Psychology, Worcester: Clark University Press, pp. 789-844.

[2] Allport G. W. (1954), The nature of prejudice. New York: Addison-Wesley.

[3] Bauman, T. (1998). O możliwości zastosowania metod jakościowych w badaniach

[4] pedagogicznych. In: T. Bauman \& Pilch, T., Zasady badań pedagogicznych. Strategie jakościowe i ilościowe. Warszawa: Wydawnictwo Akademickie „Żak”, pp. 268-269.

[5] Badelau, P.(1990). Intercultural education. Bulettin du BIE, Paris, nr. 622. UNESCO.

[6] Bleszynska, K.M. (2006). Attitudes toward race and racial equity in Polish immigrant communities. In: C. A., Grant, and A. Portera (eds.). Intercultural and Multicultural Education: Enhancing Global Interconnectedness. London: Routledge.

[7] Delors, J. (1996). Learning: The Treasure Within. Report to UNESCO of the International Commission on Education for the Twenty-first Century. UNESCO.

[8] Ebrahim, G. J. (1995). Mother and Child Health: Research Methods. Journal of Tropical Pediatrics, Oxford University Press.

[9] Eagly, A.H., Chaiken, S. (1993). The Psychology of Attitudes. Fort Worth.Harcourt: Brace, \& Janovich.

[10] Eyal, G. (2006). The Disenchantment of the Orient. Palo Alto, CA: Stanford University Press.

[11] Foley, D. E. (1995). The heartland chronicles. Philadelphia: University of Pennsylvania.

[12] Friesen, N. (2014). Waldenfels' Responsive Phenomenology of the Alien: An Introduction. Phenomenology \& Practice, 7(2), 68-77.

[13] Guilford, J.P. (1968). Intelligence, Creativity and their Educational Implications. San Diego: R.R. Knapp.

[14] Habermas, J. (2005). Die Einbeziehung des Anderen. Studien zur politischen Theorie, Frankfurt a.M.: Suhrkamp.

[15] Haike, F. (2008). Embracing oneself and the other. In: D.M. Mohr (ed.). Embracing the Other: Addressing Xenophobia in the New Literatures in English. New York: Asnel Papers. Rodopi. 
[16] Kubica G. \& Rusek H., (2014). Granice i pogranicza: państw, grup, dyskursów... Perspektywa antropologiczna i socjologiczna. Katowice: Wydawnictwo Uniwersytetu Śląskiego.

[17] Leistle, B. (2014). From the Alien to the Other: Steps toward a Phenomenological Theory of Spirit Possession. Anthropology of consciousness. Volume 25, issue 1, pp. 53-90.

[18] Lugo, A. (1997). Reflections on border theory, culture, and the nation. In D. E. Johnson and S. Michaelson (Eds.), Border theory. Minneapolis: University of Minnesota, pp.43-67.

[19] Łukaszewski, W. (1974). Osobowość: struktura i funkcje regulacyjne, Warszawa: PWN.

[20] MacDonald, S. \& Headlam, N. (2009). Research Methods Handbook. Introductory guide to research methods for social research. Manchester: Express Networks.

[21] Macrae, C., Ch. Stangor, and Hewstone M. (1996). Stereotypes and Stereotyping. New York: The Guilford Press.

[22] Menga, F. G. (2011). Guest Editor's Preface: The Experience of the Alien and the Philosophy of Response. Etica \& Politica / Ethics \& Politics, XIII, 2011, 1,pp. 7-15

[23] Međvedović, Š. (1996). Bosanska srednjovjekovna država i suvremenost, Sarajevo: Zbornik FPN.

[24] Nikitorowicz, J. (1995). Pogranicze. Tożsamość. Edukacja międzykulturowa. Białystok: Trans Humana.

[25] Pilarska, J. (2011). Boszniacy - szczęśliwi Muzułmanie Europy (?) czyli Dżihad kontra McŚwiat i inne teorie... In: A. Kobylarek (ed.). Ogrody nauk i sztuk - debiuty 2010. Wrocław: Wydawnictwo ARGI, pp. 121-132.

[26] Seidman. S. (2013). Defilement and disgust: Theorizing the other. American Journal of Cultural Sociology. (2013) 1, 3-25. doi:10.1057/ajcs.2012.3.

[27] Smith E. R., D. M. Mackie and Claypool H. M., Social Psychology. New York/ London: Psychology Press.

[28] Tajfel, H. \& Turner, J. C. (1979). An Integrative Theory of Intergroup Conflict. In: W. G. Austin and S. Worchel (eds.). The Social Psychology of Intergroup Relations. Monterey CA: Brooks-Cole.

[29] Waldenfels, B. (1987). Ordnung im Zwielicht. Frankfurt a.M.: Suhrkamp.

[30] Waldenfels, B. (1995). Response to the Other. In: G. Brinker-Gabler (ed.). Encountering the Other(s). Studies in Literature, History and Culture. New York: State University of New York Press.

[31] Waldenfels, B. (2011). Phenomenology of the alien: Basic concepts. Northwestern: Evanston.

[32] Waldenfels, B. (2007). The Question of the Other. Albany: SUNY Press.

[33] Wełnic, E \& Fisiak J. (2008). Friendly Metaphors: Essays on Linguistics, Literature and Culture in Honour of Aleksander Szwedek. Frankfurt am Main: Peter Lang.

[34] Wilska-Duszyńska, B. (1971). Rozważania o naturze stereotypów. Studia Socjologiczne 11, pp. 97-116.

[35] Zajonc, R. B. (1968). Attitudinal effect of mere exposure. Journal of Personality and Social Psychology, Vol 9 (2, Pt.2), June 1968, pp. 1-27.

[36] Žiga, J. (2001). The tradition of Bosnia which has been betrayed. Sarajevo: Vijeće Kongresa bošnjačkih intelektualaca. 